\title{
Characterization of Human Villous and Extravillous Trophoblasts Isolated from First Trimester Placenta
}

\author{
Anne Tarrade, René Lai Kuen, André Malassiné, Viviane Tricottet, Pascal Blain, \\ Michel Vidaud, and Danièle Evain-Brion
}

INSERM Unité 427 (AT, AM, DE-B), Laboratoire de Microscopie Electronique (RLK, VT), and Laboratoire de Génétique Moléculaire (MV), Université René Descartes, Faculté des Sciences Pharmaceutiques et Biologiques de Paris, Paris; and Laboratoire de Foeto-Pathologie (PB), Hôpital Robert Debré, Paris, France

\begin{abstract}
SUMMARY: Trophoblasts of the human placenta differentiate along two pathways to give either extravillous cytotrophoblasts (EVCT) with invasive properties and that are implicated in the implantation process, or villous cytotrophoblasts (VCT) that by cell fusion form multinucleated syncytiotrophoblasts. We report the first isolation and purification of these two cell types from the same chorionic villi of first trimester human placenta. We also studied their differentiation in vitro. Electron microscopy showed that in contrast to VCT, EVCT had no microvilli but contained large fibrinoid inclusions. EVCT cultures required a matrix to invade, and as previously established, VCT cultured on plastic dishes aggregated and fused to form syncytiotrophoblasts. These differentiation processes were characterized by a particular pattern of gene expression as assessed by real-time PCR and confirmed by immunocytochemical analysis of the corresponding proteins. EVCT cultured in vitro expressed high levels of HLA-G, c-erbB2, human placental lactogen, and very little human chorionic gonadotropin. Interestingly, TGF $\beta 2$ was a marker of EVCT in vitro and in situ. These data offer a new tool for cell biologists to study the molecular mechanisms involved in human placental development and its pathology. (Lab Invest 2001, 81:1199-1211).
\end{abstract}

$I$ n mammals, embryonic development requires a placenta that forms by implantation of the blastocyst in the maternal organism. The placenta is an autonomous and transitory organ that allows nutritional and gas exchanges between the fetus and the maternal organism. In addition, the endocrine and immunological functions of the placenta are essential in pregnancy and for fetal growth. The human placenta is characterized by extensive invasion of trophoblasts into the maternal uterus, allowing direct contact of trophoblasts with the maternal blood (hemomonochorial placentation) (Aplin, 1991; Benirschke and Kaufmann, 2000), and by the extent and specificity of its hormonal production (Redman et al, 1993). In this tissue, steroid (Albrecht and Pepe, 1990) and protein hormones, such as human chorionic gonadotropin (hCG; Jameson and Hollenberg, 1993), human placental lactogen (hPL; Handwerger, 1991), and placental growth hormone (PGH; Alsat et al, 1997), are produced in large amounts, unparalleled in other mammals.

After the initial phase of nidation, human trophoblasts differentiate along either the villous or the extravillous trophoblast pathway (Alsat et al, 1999;

Received March 20, 2001.

This study was supported by a grant from Fondation pour la Recherche Médicale (ARS 2000).

Address reprint requests to: Dr. Danièle Evain-Brion, INSERM Unité 427, Université René Descartes, Faculté des Sciences Pharmaceutiques et Biologiques de Paris, 4 Avenue de l'Observatoire, F-75270 Paris Cedex 06, France.E-mail:U427@pharmacie.univ-paris5.fr
Kaufmann and Scheffen, 1990; Loke and King, 1995). Villous trophoblasts cover the chorionic villi and are involved in the exchange of gas and nutriments between the mother and the fetus. Extravillous trophoblasts invade deep into the uterus wall (as far as the myometrium) and are directly implicated in the anchoring of chorionic villi in the uterus.

Because of the specificity of the human placenta, animal models are not suitable. Therefore in vitro models are necessary to study the differentiation process of the human trophoblast. Isolation and purification of villous trophoblast cells from human term placentas has been described during the last 10 years. Isolated mononuclear cytotrophoblasts aggregate and fuse to form an endocrine-active multinucleated syncytiotrophoblast (ST) (Alsat et al, 1991; Keryer et al, 1998; Kliman et al, 1986). The extravillous trophoblasts involved in the implantation process have been characterized more recently. Immunohistochemical studies on placental bed biopsies reveal that the cells at the tip of some of the villi that contact the uterine wall detach from the basement membrane and aggregate into multilayered columns of nonpolarized cells that rapidly invade the uterus. In contrast to tumoral invasion, this trophoblastic invasion is precisely regulated, confined spatially to the endometrium, the first third of the myometrium, and the associated spiral arterioles and confined temporally to early pregnancy (Boyd and Hamilton, 1970). Expression of integrins (Damsky et al, 1992, 1994), cell adhesion molecules (Redman, 1997; Zhou et al, 1993, 1997a, 1997b), and metalloproteases (Bischof et al, 1995; Damsky et al, 
1992; Lala and Hamilton, 1996; Maquoi et al, 1997) throughout this migration has been well documented by immunohistochemistry and in situ hybridization. In addition, these extravillous trophoblasts express specific HLA antigens, such as HLA-G, which are directly involved in avoiding maternal rejection (Kovats et al, 1990; Le Bouteiller and Blaschitz, 1999). On the other hand, very few studies have been conducted to characterize these extravillous trophoblasts in vitro. These cells are currently obtained after enzymatic digestion (Genbacev et al, 1997; Librach et al, 1991; Rong-Hao et al, 1996) or derive from a placental explant (Caniggia et al, 1999; Haigh et al, 1999; Lala et al, 1999).

Therefore, the aim of this study was, for the first time, to isolate, with gentle enzymatic digestion and purify from the same chorionic villi of first trimester human placenta, villous and extravillous trophoblast cells and to culture them in vitro. Cells were observed by electron microscopy and characterized by the comparative level of expression of specific genes quantified by real-time PCR. In addition, we established the level of expression of TGF $\beta 2$ in extravillous cytotrophoblasts (EVCT), suggesting a role for this growth factor at the fetomaternal interface.

\section{Results}

\section{Differentiation Pathway of Human Trophoblasts}

The functional and structural unit of the human placenta is the chorionic villi. These villi are either anchored in the uterus wall or floating in the intervillous space. A summary of human trophoblast cell differentiation in the chorionic villi is shown in Figure $1 \mathrm{~A}$. Mononuclear cytotrophoblast stem cells derived from the trophoblast surrounding the blastocyst can follow two pathways. At the tip of the anchoring villi, illustrated in Figure 1B, the cytotrophoblasts proliferate and differentiate into extravillous trophoblasts with invasive properties. These EVCT migrate through the decidua and invade the spiral arterial walls (Fig. 1C). They end their migration in the lumen of the spiral arteries and replace the endothelial cells. They also form giant cells, bi- or trinucleated inside the decidua (Al-Lamki et al, 1999). On the other hand, the cytotrophoblasts on the border layer of the floating villi differentiate by cell-cell fusion into ST (Vicovac and Aplin, 1996).

\section{In Vitro Culture of Villous and Extravillous Trophoblasts}

From the same chorionic villi from first trimester placenta (Fig. 2, left panel), cytotrophoblasts were isolated by differential enzymatic digestion. After 35 minutes of enzymatic digestion, EVCT were obtained (Fig. 2, middle panel) and the remaining villous cytotrophoblasts (VCT) were isolated after further sequential enzymatic digestion (Fig. 2, right panel). We used light microscopy (Fig. 3A) and electron microscopy (Fig. 3B) to show that VCT aggregate and fuse on plastic culture dishes within 24 to 48 hours, forming a syncytium (Fig. 3A, middle and right panels), thus confirming earlier studies (Alsat et al, 1991; Keryer et al, 1998). We also showed the interaction, aggregation, and fusion of mononuclear cells. After 48 hours of culture, scanning electron microscopy allowed us to observe large cellular masses with central nuclear mounds and extending cytoplasm (Fig. 3B, insert of right panel). The cell surface exhibited numerous microvillous projections and cytoplasmic extensions. In addition we checked by immunocytochemistry that the integrin subunits expressed by this cell population in vitro were the $\alpha 6$ (Fig. 4A). On the other hand, when EVCT were cultured, they did not adhere to plastic culture dishes and died within 24 hours. However, EVCT cultured on Matrigel $(5 \mathrm{mg} / \mathrm{ml})$ adhered and could be cultured for at least a week (Fig. 3A, left panel). Electron microscopy of extravillous trophoblasts showed a well-developed rough reticulum, many Golgi complexes, and intermediary filaments bundles (Fig. 3B, left panel). In vitro immunocytochemical analysis of this population of EVCT demonstrated the presence of the $\alpha 5$ integrin subunit (Fig. 4B). In addition, the EVCT never fused, but migrated and invaded the Matrigel (Fig. 4C). In comparison, VCT isolated from the same chorionic villi never expressed the $\alpha 5$ integrin subunit and were embedded and fixed on the Matrigel.

\section{Gene Expression in Villous and EVCT}

Real-time PCR was used to determine the levels of transcripts of membrane protein markers of EVCT that have been previously defined on placental sections, such as HLA-G (Kovats et al, 1990) and c-erbB2 (Jokhi et al, 1994; Mühlhauser et al, 1993), in EVCT cultured for 48 hours. This study was also conducted in comparison with VCT isolated from the same placenta sample, before and after their in vitro differentiation into ST. Interestingly, as shown in Figure 5, we confirmed that the level of c-erbB1 increases with ST formation (Alsat et al, 1996) and that cultured EVCT have low levels of expression of this gene. Similarly, we confirmed the large increase in $\mathrm{hCG} \alpha$, hCG $\beta$, and $\mathrm{hPL}$ transcripts (Jacquemin et al, 1996) during the differentiation of VCT into ST. Interestingly, the levels of $\mathrm{hCG} \alpha$ and $\mathrm{hCG} \beta$ mRNA were very low in EVCT. On the other hand, we clearly observed that these cultured EVCT expressed hPL in vitro (Fig. 6). In addition, the purity of our preparation of EVCT was checked by quantifying the transcript levels of two genes specifically expressed in the ST, ie, INSL4 (Laurent et al, 1998) and leptin (Masuzaki et al, 1997; Senaris et al, 1997). As shown in Figure 7, the level of these two transcripts was very low in cultured EVCT, demonstrating the absence of contamination by ST.

\section{Immunocytochemical Characterization of Cultured EVCT}

We then further characterized the expression of different markers of EVCT by immunocytochemistry and Facs scan analysis. As shown in Figure 8, we observed that our population of isolated EVCT was $97 \%$ pure as analyzed by double labeling using antibodies against cytokeratin 7 , a specific marker of trophoblast 


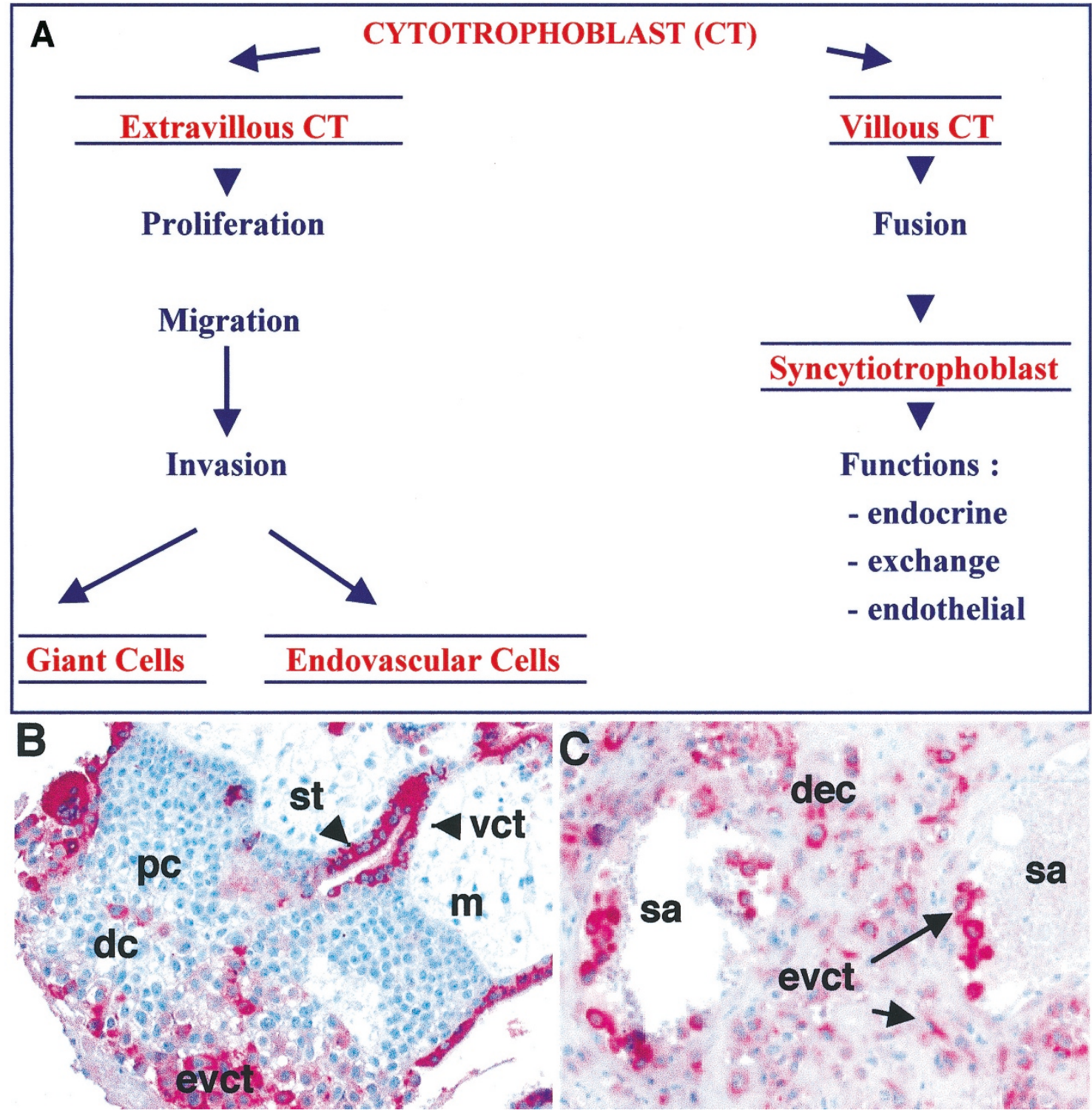

\section{Figure 1.}

The two differentiation pathways of human cytotrophoblasts. The key cell of the human placenta is the cytotrophoblast. These cells can follow two different differentiation pathways: villous and extravillous (A). At the anchoring villi (B), the extravillous cytotrophoblasts (EVCT) are localized at the proximal column, proliferate, and never express the human placenta lactogen (hPL). At the distal column, EVCT are invasive; these cells are detected by hPL immunolabeling (red). $\mathrm{hPL}$ labeling shows EVCT migrating through the decidua, invading the spiral arteries, and replacing the endothelial cells (C). In the chorionic villi, villous cytotrophoblasts (VCT) fuse to form a multinucleated syncytiotrophoblast (ST) (B) that covers the chorionic villi and expresses hPL. The ST has endocrine, exchange, and endothelial functions. $d c$, distal column; dec, decidua; evct, extravillous cytotrophoblasts; $m$, mesenchyme; pc, proximal column; sa, spiral arteries; st, syncytiotrophoblast; vct, villous cytotrophoblasts.

cells (Cervar et al, 1999), and hPL. In addition, these EVCT cells expressed c-erbB2 (Fig. 8) and, in contrast to VCT and ST, the cytotrophoblasts strongly expressed HLA-G protein (Fig. 9A) as detected by immunocytochemistry. This analysis was confirmed by Facs scan analysis, studying HLA-G expression (Fig. 9B). In addition, using the same approach, we checked that this cell preparation was negative for specific markers of endothelial cells (Willebrand factor), macrophages (CD14), and lymphocytes (CD45).

\section{TGF 32 Expression in Human EVCT}

Interestingly, we observed a very high level of expression of TGF $\beta 2$ in cultured EVCT, as shown by immu- nocytochemistry (Fig. 10B) and mRNA levels studied by real-time PCR (Fig. 10A). The high expression of TGF $\beta 2$ in EVCT was then confirmed in situ by immunohistochemistry (Fig. 10C). TGF $\beta 2$ was also shown to be expressed in the ST by real-time PCR and by immunohistochemistry (Fig. 10, A and C).

\section{Discussion}

Human cytotrophoblasts are the key cells in placental development, both EVCT in the implantation process and VCT in growth support and the multiple exchange and endocrine functions of the placenta. In this study, we compared for the first time morphological aspects 


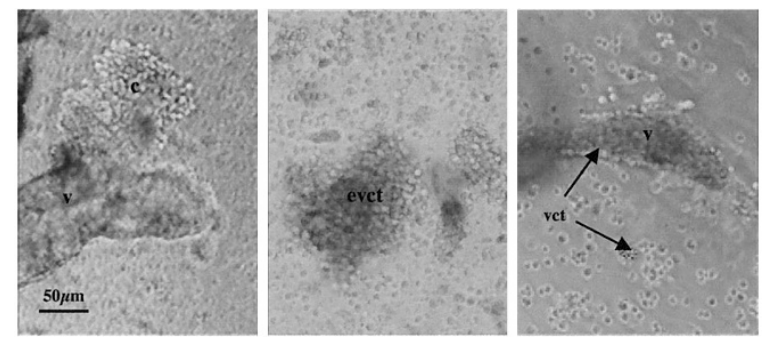

Figure 2.

Aspect of chorionic villi before enzymatic digestion (left panel). EVCT from a column appear easily accessible as a cluster of aggregated cells. After 35 minutes of digestion, the enzymatic digestion medium (middle panel) contained clusters of aggregated EVCT, few ST fragments and erythrocytes. The VCT are isolated after further sequential digestion and appear in the digestion medium as many round refringent isolated cells. Others are still fixed around the mesenchyme core of the chorionic villi (right panel). c, column; evct, extravillous trophoblast; $v$, chorionic villi; vct, villous cytotrophoblast.
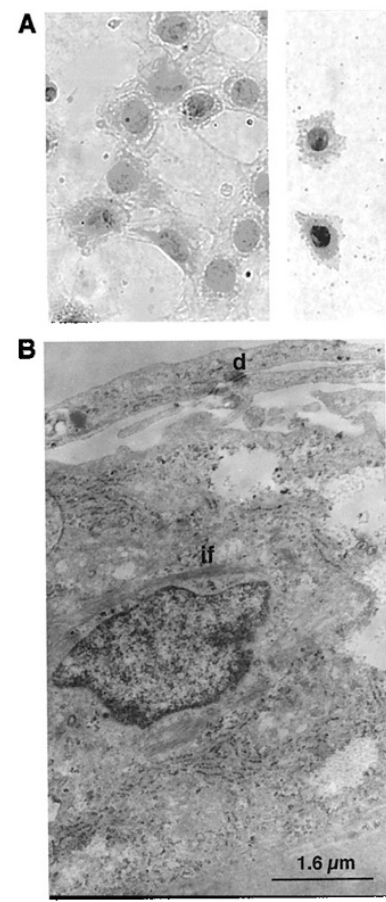

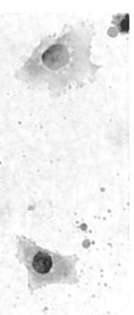

1
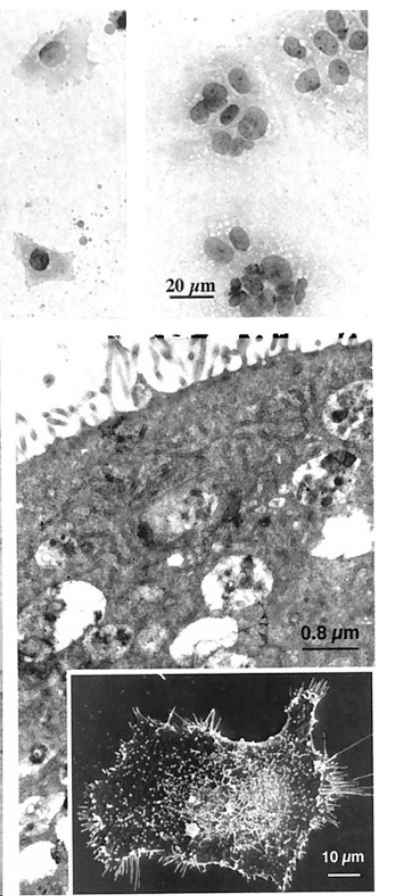

\section{Figure 3 .}

A, Light microscopy observation of VCT cultured on a plastic dish for 24 hours (middle panel) or 48 hours. In culture, they fused to form multinucleated ST (right panel), whereas EVCT cultured on Matrigel (left panel) never fused (scale bar, $20 \mu \mathrm{m}$ ). B, Transmission electron micrograph of extravillous phenotype cytotrophoblasts cultured for 48 hours on Matrigel (left panel). Cell aggregates are observed without cell fusion. Trophoblasts have a smooth plasma membrane and a well-developed rough reticulum, and many Golgi complexes and intermediary filament bundles (if). A desmosome $(d)$ is shared with adjacent cytotrophoblastic cells (scale bar, $1.6 \mu \mathrm{m}$ ). Transmission (right panel) and scanning electron microscopy (inset of right panel) of villous phenotype trophoblasts cultured for 48 hours on plastic dishes. After cellular fusion, polarized multinucleated cells, identical to the ST, are observed. The cell surface exhibits a typical microvillous membrane. The cytoplasm contains the usual cytoplasmic organelles and a well-developed endocytic apparatus (scale bar, $0.8 \mu \mathrm{m}$ ). Scanning electron micrograph of a multinucleated ST showing a central nucleus mount and an extended cytoplasm with microvilli (insert of right panel) (scale bar, $10 \mu \mathrm{m}$ ).

in the culture of these two populations of trophoblasts, after isolation from first trimester human placentas. Our cell isolation procedure was adapted from a previous study (Loke and Burland, 1988). The procedure was based on the intensity of the enzymatic digestion of the anchoring chorionic villi. Indeed, as illustrated in Figure 1, EVCT from the column are directly accessible to enzymatic digestion and are released from the tissue in aggregates of cells, whereas the VCT, located under the ST layer in the tissue, needed a more intense enzymatic digestion. As previously established (Alsat et al, 1991; Kliman et al, 1986) a Percoll purification gradient was necessary to purify the VCT and eliminate mesenchymal, endothelial, and macrophage contaminations. On the other hand, we isolated a large population of EVCT by controlled enzymatic digestion. During this process, the length of enzymatic digestion, the bath of trypsin used, and the absence of agitation are critical steps to monitor. The different immunocytochemical studies performed on these EVCT confirmed the presence of cytokeratin 7 , specifically expressed in the trophoblast cells (Cervar et al, 1999). We also checked the absence of fibroblastic contamination by vimentin immunostaining of immunocompetent cells from the decidua by CD45 and of endothelial cells by antiWillebrand factor immunostaining.

As is already well established (Alsat et al, 1991; Cronier et al, 1994; Kliman et al, 1986), we confirmed that VCT adhere to the plastic dish, aggregate, and fuse to form ST. VCT, isolated from the chorionic villi, possess multiple microvilli at their cell surface as shown in this study by scanning electron microscopy (Anne Tarrade, personal observation). Although the cytotrophoblast fusion occurs in a smooth area of the plasma membrane (Jones and Fox, 1991), a role of microvilli in the cytotrophoblast fusion process cannot be excluded, as already suggested in other cell types (Wilson and Snell, 1998). Interestingly, we recently showed (Cronier et al, 1997; Keryer et al, 1998) that this fusion process was clearly increased by cAMP. It was associated with a disappearance of the type I protein kinase $A(P K A)$ regulatory subunit and a relocation of the type II underneath the plasma membrane, suggesting that PKA type II, when bound to specific anchoring proteins (AKAP), may be a major partner of membrane reorganization associated with cell fusion and microvilli formation. VCT expressed the $\alpha 6$ and $\beta 4$ integrin subunits. In contrast, EVCT did not attach to plastic dishes and needed a matrix, such as Matrigel used in this study, to be cultured in vitro. These cells never fused and, in contrast, migrated on and invaded the Matrigel. They expressed the $\alpha 5$ integrin subunit, the receptor for the fibronectin.

We have compared for the first time, using real-time PCR, the levels of expression of different genes in villous and extravillous trophoblasts in culture after isolation from the same placental sample. We first used this powerful method to characterize these cells by studying the transcript levels of specific markers. We confirmed that the morphological differentiation of VCT into ST in vitro is associated with a functional endocrine differentiation: the expression of pregnancy-specific hormones such as hCG (Jameson and Hollenberg, 1993), hPL (Handwerger, 1991), leptin 

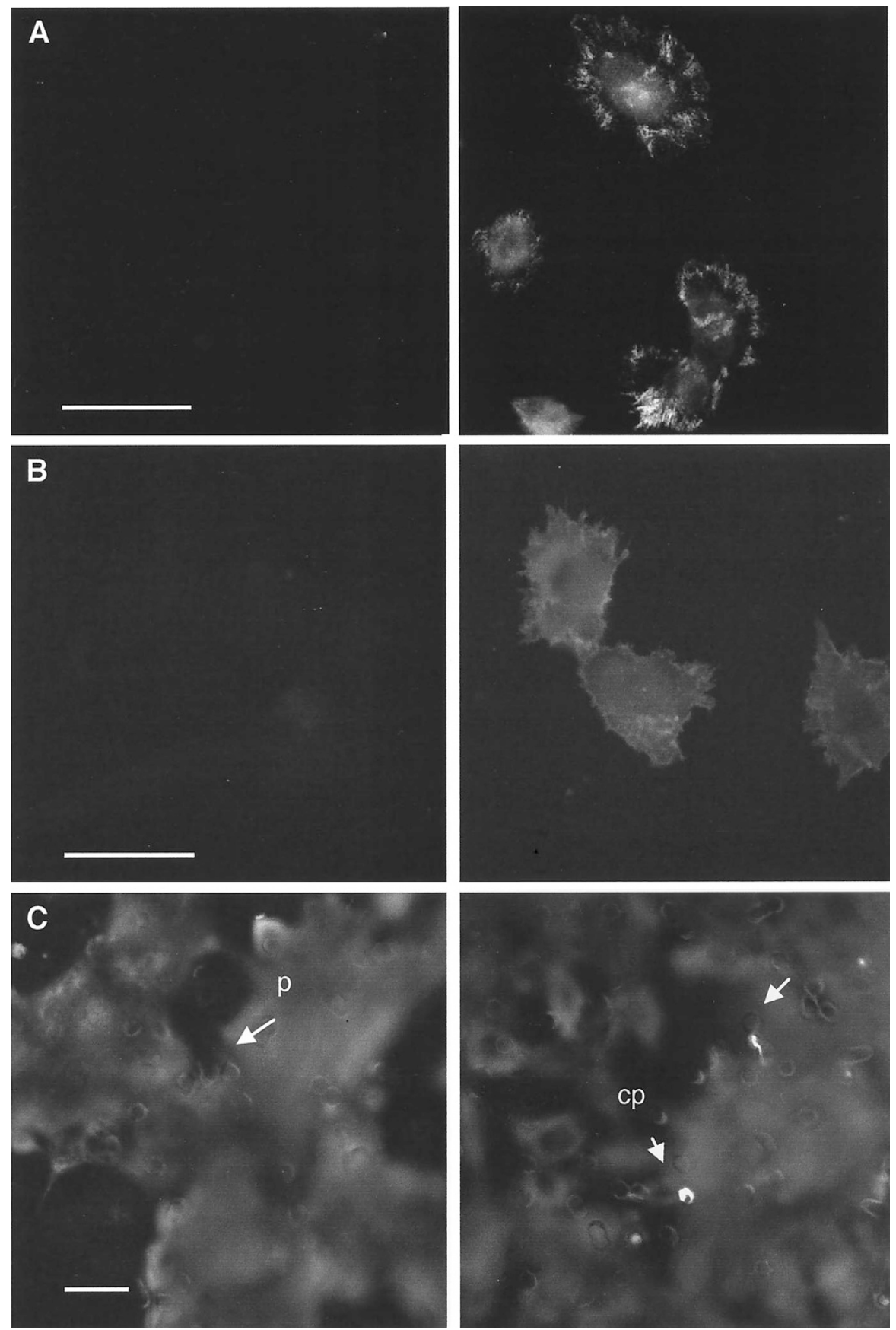

\section{Figure 4.}

Immunostaining of the $\alpha 6$ integrin subunit in VCT (A) and $\alpha 5$ integrin subunit in human isolated EVCT cultured 48 hours on Matrigel (B) (scale bar, $50 \mu \mathrm{m})$. The villous and extravillous trophoblasts show respectively a strong labeling of $\alpha 6$ and $\alpha 5$ (right panel) compared with the lgG isotypic control (left panel). C, Invasion assays. Extravillous trophoblasts isolated from first trimester placenta were cultured on Matrigel-coated Transwell filters. After 24 and 48 hours, cells were fixed and stained with anticytokeratin 07 antibody. The filters were removed from the inserts and the top of the filter was placed in contact with a slide. Transwells were examined on an epifluorescence microscope. By 24 hours (left panel), the labeled cells were present only on the upper surface and the pores $(p)$ appear black. By 48 hours (right panel), fluorescently labeled (cytokeratin-positive) cell projections $(c p)$ appear in the pores (scale bar, $50 \mu \mathrm{m}$ ).

(Guibourdenche et al, 2000; Masuzaki et al, 1997), and INSL4 (Laurent et al, 1998) specifically takes place in the ST. Indeed, in vitro ST formation was associated with large increases in $\mathrm{hCG} \alpha, \mathrm{hCG} \beta, \mathrm{hPL}$, and leptin mRNA. Interestingly, leptin and INSL4 expression appeared to be specific to the ST and was not observed in EVCT. This observation confirmed the purity of our preparations of cultured EVCT, which were not con- taminated by fragments of ST. Using real-time PCR, we also confirmed in vitro in cultured EVCT the expression of specific markers of EVCT described in situ in the anchoring villi. For example c-erbB2 (Jokhi et al, 1994; Mühlhauser et al, 1993), which was highly expressed in EVCT but not in VCT, appears to be a marker specific to the extravillous pathway and HLA-G, which is involved in the complex immunolog- 

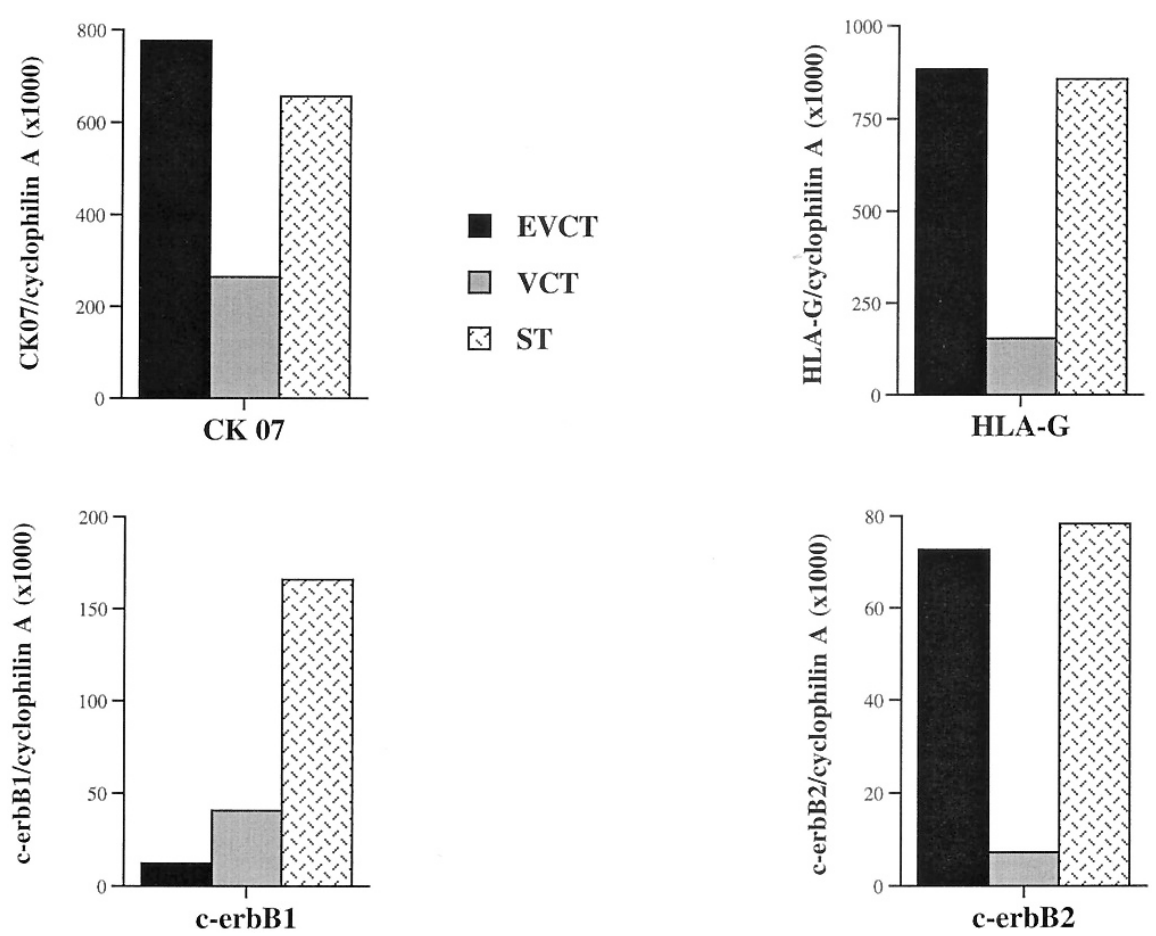

Figure 5.

Gene expression of cytokeratin 07, HLA-G, c-erbB1, and c-erbB2 in EVCT cultured for 2 days on Matrigel and villous cytotrophoblast (VCT) at Days 0 and 3 (when they have fused to form multinucleated ST) after plating on plastic culture dishes. mRNA data are expressed as the level of each marker mRNA normalized by cyclophilin A mRNA. Three culture dishes were pooled for each determination of transcript levels and were assayed in duplicate.
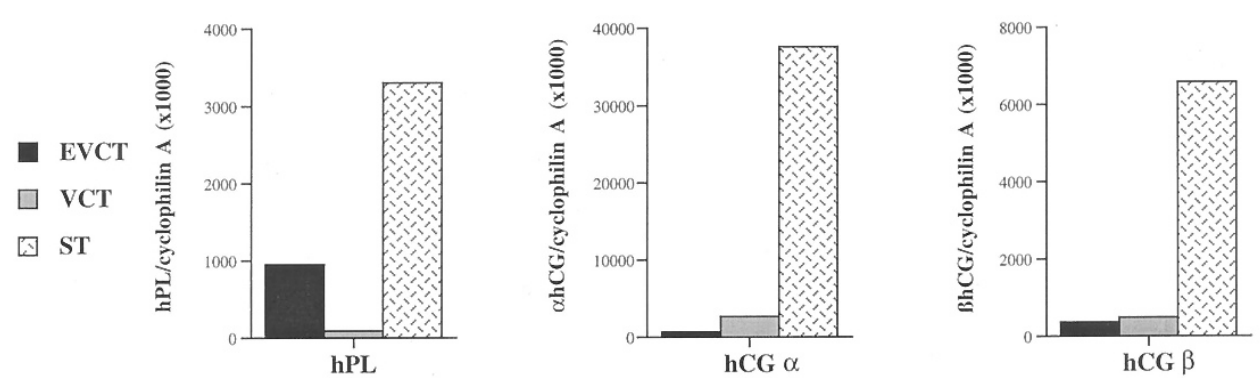

Figure 6.

Gene expression of hPL, $\alpha \mathrm{hCG}$, and $\beta$ hCG in EVCT cultured for 2 days on Matrigel and VCT at Days 0 and 3 (when they have fused to form multinucleated ST) after plating on plastic culture dishes. mRNA data are expressed as the level of each marker mRNA normalized by cyclophilin A mRNA. Three culture dishes were pooled for each determination of transcript levels and were assayed in duplicate.

ical cross talk between the trophoblast and the maternal immunocompetent cells of the uterus (Le Bouteiller and Blaschitz, 1999). The protein expression of such markers was confirmed by immunocytochemistry. Interestingly, as confirmed in this study, VCT and ST expressed HLA-G mRNA but not HLA-G protein, suggesting a posttranscriptional difference between the villous and the extravillous trophoblast pathway (Copeman et al, 2000). In addition, in this study we confirmed that hPL, which is highly expressed in the ST, is also a marker of invasive EVCT (Genbacev et al, 1993). Indeed, in this study we observed the RNA and protein expression of hPL in EVCT in culture. The role of this hormone in these cells remains unknown.

In addition, using the same methodology, we demonstrated high levels of TGF $\beta 2$ transcripts in EVCT as well as in ST. The expression of TGF $\beta 2$ in EVCT was confirmed in situ using placental tissue sections and in cultured cells using a specific antibody. TGF $\beta$ are multifunctional cytokines that carry proliferation and differentiation signals (Sporn and Roberts, 1992). In addition, TGF $\beta$ are considered to regulate the deposition of extracellular matrix by increasing its synthesis and down-regulating its degradation by proteases. It is therefore thought to be involved in modulation of trophoblast invasion (Caniggia et al, 1999; Graham and Lala, 1992; Strickland and Richards, 1992). The three isoforms, TGF $\beta 1$, TGF $\beta 2$, and TGF $\beta 3$, have been identified at the human maternal interface (Ando et al, 1998; Chen et al, 1993; Graham and Lala, 1992; Vuckovic et al, 1992) by in situ hybridization and immunohistochemistry. A predominant expression of TGF $\beta 1$ in the villous tissue and of TGF $\beta 2$ in the decidual tissue has been observed (Altman et al, 1990; 

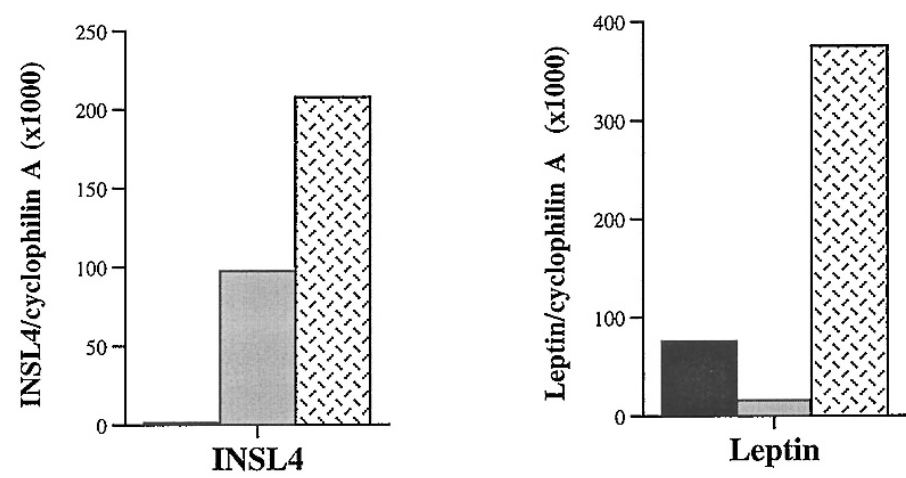

EVCT

VCT

ST

Figure 7.

Gene expression of INSL4 and leptin in EVCT cultured for 2 days on Matrigel and VCT at Days 0 and 3 (when they have fused to form multinucleated ST) after plating on plastic culture dishes. mRNA data are expressed as the level of each marker mRNA normalized by cyclophilin A mRNA. Three culture dishes were pooled for each determination of transcript levels and were assayed in duplicate.

Non specific lgG

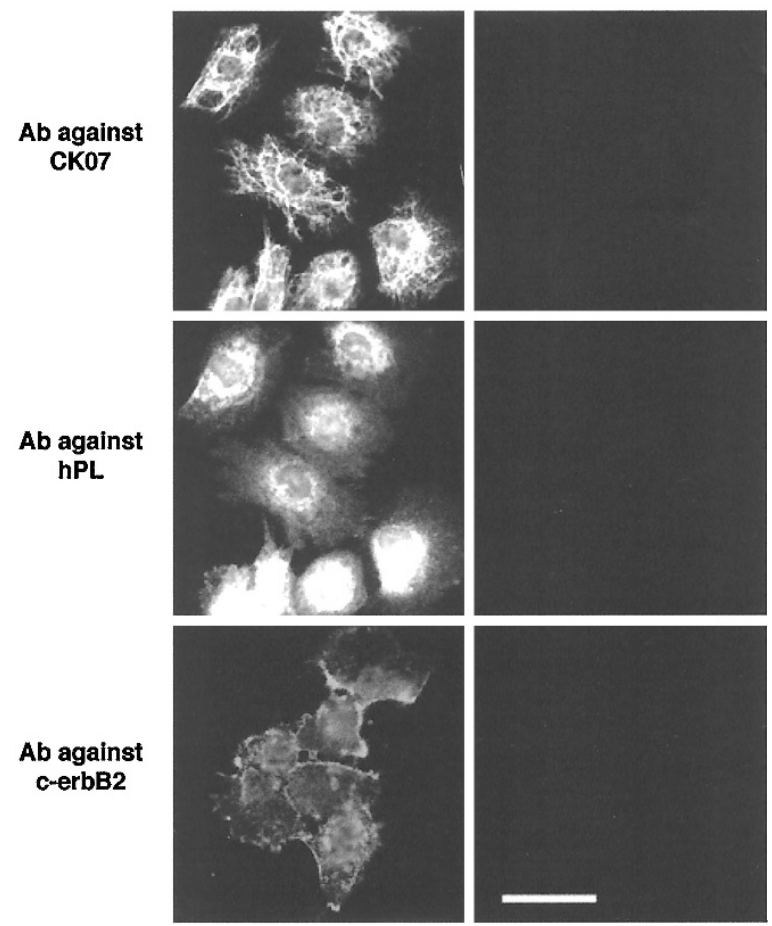

Figure 8.

Immunodetection of cytokeratin 07 (CK 07), hPL, and c-erbB2 in human isolated extravillous trophoblasts cultured for 48 hours. Double labeling for CK 07 (upper panel) and hPL (center panel) revealed different localizations of staining. C-erbB2 is expressed at the periphery of the cells (lower panel; scale bar, $50 \mu \mathrm{m})$

Selick et al, 1994). On the other hand, the role of the other isoforms of TGF $\beta$ is still poorly understood. Because TGF $\beta 2$-like molecules are released by CD56+ natural killer cells and act as an immunosuppressive factor, implication of TGF $\beta 2$ in a local immune reaction preventing rejection of allograft has been suggested (Clark et al, 1994; Lea et al, 1995). This may be the case for TGF $\beta 2$ expressed by extravillous cytotrophoblast. Despite the fact that the role of TGF $\beta 2$ has yet to be elucidated, the high level of expression of this cytokine offers a new and valuable marker for extravillous trophoblast characterization in situ and in vitro.

In conclusion, in this study we established an original model for the isolation and purification from the human placenta of the two types of trophoblast cells: villous and extravillous trophoblasts. We showed that the comparative analysis of multiple gene expression by real-time PCR may aid in the characterization of these cells and the purity of the cell preparations. These results offer a new tool for cell biologists to study, in vitro at the cellular level, the molecular mechanisms involved in the human placental development and its pathology. Human trophoblast invasiveness offers a unique model to study invasion of normal nontransformed cells. Indeed, in contrast to tumoral invasiveness, trophoblast invasion is precisely regulated and controlled. A defect of this trophoblast invasion is directly involved in the serious and specific complication of human pregnancy: preeclampsia (Zhou et al, 1993, 1997a).

\section{Materials and Methods}

\section{Tissues}

Placental tissues from first trimester (7-12 weeks) legal voluntary interruption of pregnancy were obtained from the Department of Obstetrics and Gynecology at Broussais and Saint-Vincent de Paul Hospitals. The tissue was washed in $\mathrm{Ca}^{2+}{ }_{-}, \mathrm{Mg}^{2+}$-free HBSS supplemented with $100 \mathrm{UI} / \mathrm{ml}$ penicillin and 100 $\mu \mathrm{g} / \mathrm{ml}$ streptomycin. Chorionic villi were dissected, rinsed, and minced for cell isolation.

\section{Isolation and Purification of Trophoblasts Differentiating into EVCT}

Chorionic villi were incubated in HBSS containing $0.125 \%$ trypsin (Difco Laboratories, Detroit, Michigan), $4.2 \mathrm{~mm} \mathrm{MgSO}_{4}, 25 \mathrm{~mm}$ HEPES, and $50 \mathrm{Kunitz} / \mathrm{ml}$ DNase type IV (Sigma, Saint-Quentin Fallavier, France) for 35 minutes at $37^{\circ} \mathrm{C}$ without agitation.

After tissue sedimentation, the supernatant was taken and filtered (100 $\mu \mathrm{m}$ pores). HBSS was added to the tissue and sedimented twice. Trypsin digestion was stopped with $5 \%$ fetal calf serum (FCS). Cells 
A
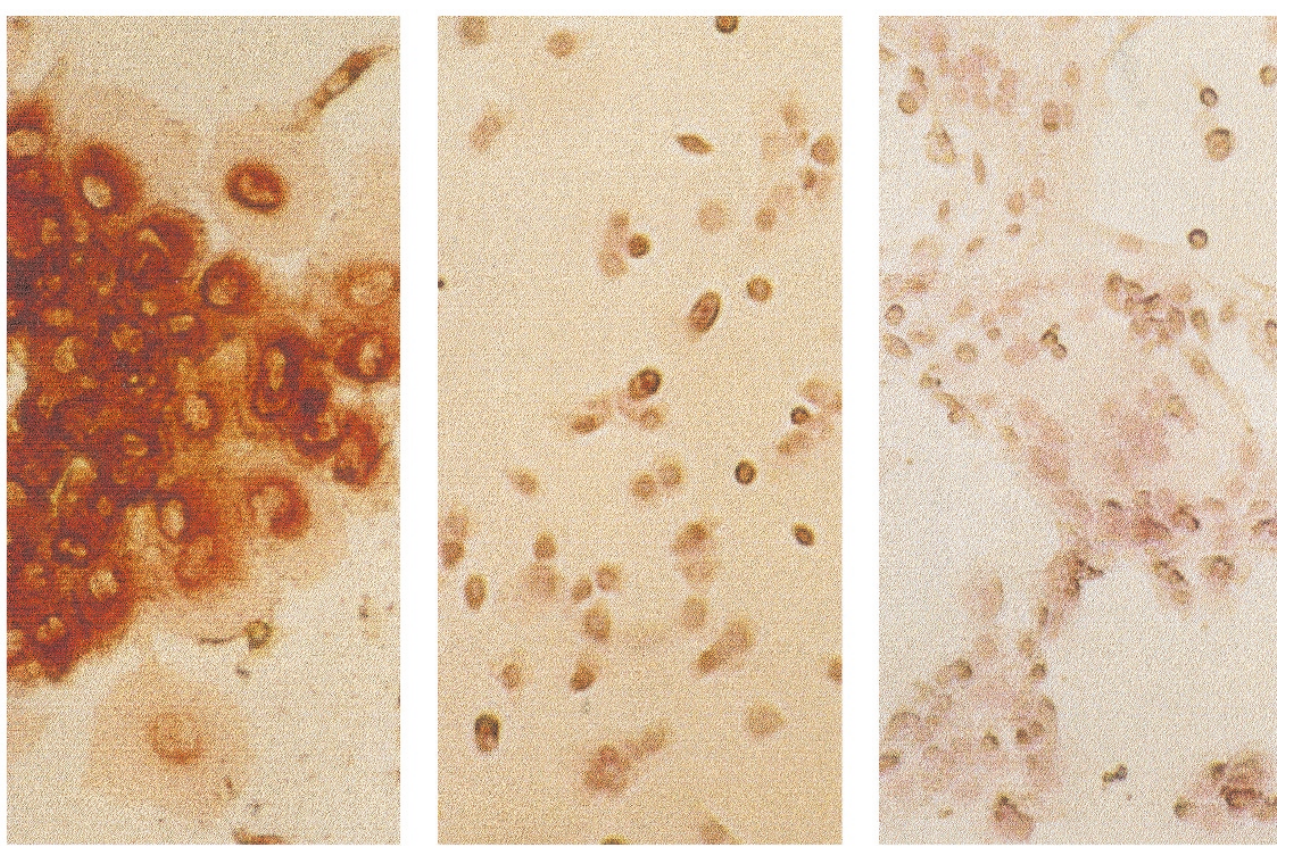

B

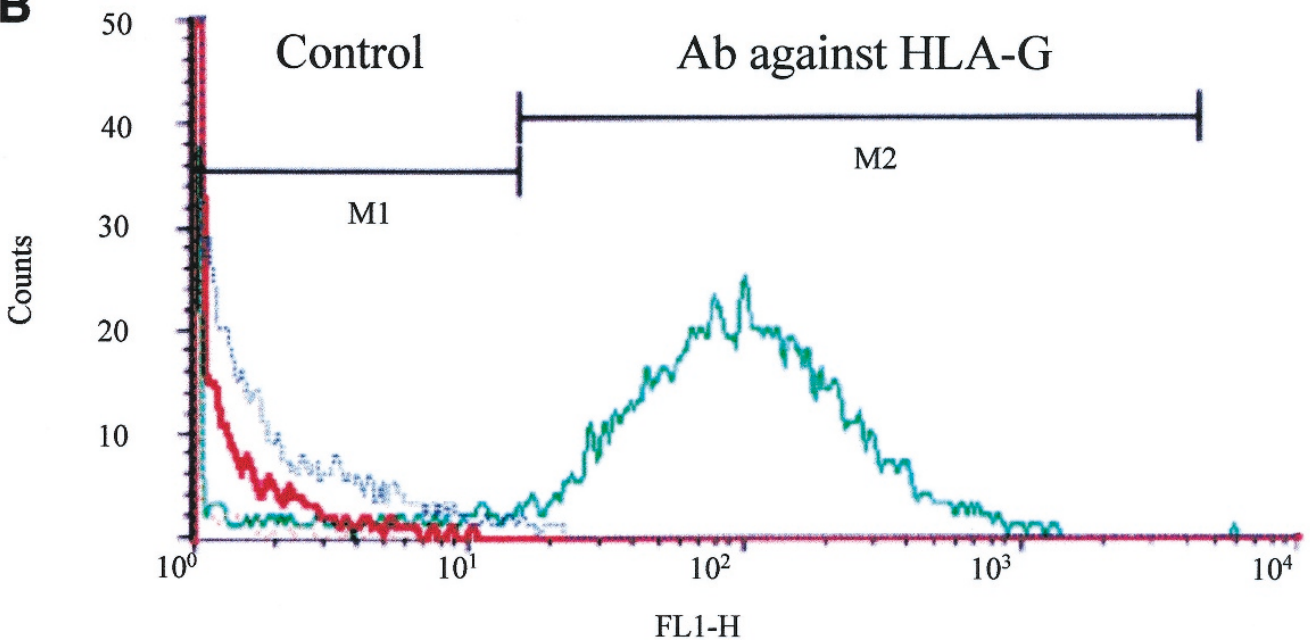

Figure 9.

A, Immunodetection of HLA-G in human isolated extravillous trophoblasts (left panel) cultured for 48 hours and in villous trophoblast (middle panel) before and after differentiation into ST (right panel). Strong immunostaining was observed in the perinuclear area of the EVCT. Staining was absent in the VCT and ST. B, Flow cytometry analysis of HLA-G expression in extravillous trophoblasts cultured for 48 hours on Matrigel. The histogram shows mean fluorescence intensity of trophoblast cells labeled with W6/32 antibody (M2) compared with the nonspecific mouse IgG 2a (M1).

were centrifuged at $300 \times g$ for 10 minutes, diluted to a concentration of $5-6 \times 10^{5}$ cells $/ 2 \mathrm{ml}$ and then plated on Matrigel-coated (5-6 mg/ml; Collaborative Biomedical Products, Le Pont de Claix, France) 35-mm Falcon culture dishes. Approximately $1.2 \times$ $10^{6} \pm 500,000$ cells were obtained per gram of chorionic villi after plating.

Cells were maintained in Dulbecco's modified Eagle's medium (DMEM; GIBCO, Grand Island, New York), supplemented with 10\% FCS (Biological Industries, Beth Haemek, Israel), 2 mм glutamine, $25 \mathrm{~mm}$ HEPES, $100 \mathrm{Ul} / \mathrm{ml}$ penicillin, and $100 \mu \mathrm{g} / \mathrm{ml}$ streptomycin, and incubated in $5 \% \mathrm{CO}_{2}$ at $37^{\circ} \mathrm{C}$. After 3 hours, cells were washed three times to eliminate all the debris and incubated with complete medium.
Cells obtained by this isolation procedure where analyzed by transmission electron microscopy before plating and after 48 hours. The expression of different genes was assessed by real-time PCR and immunocytochemistry.

\section{Isolation and Purification of Cytotrophoblasts Differentiating into VCT}

After EVCT isolation, the same chorionic villi were submitted to the sequential trypsin-DNase digestions at $0.25 \%$ as previously described (Alsat et al, 1991; Kliman et al, 1986). Cell suspensions were carefully layered over a discontinuous Percoll Gradient (70\% to $5 \%$, in $5 \%$ steps) and centrifuged. The middle layer 
A
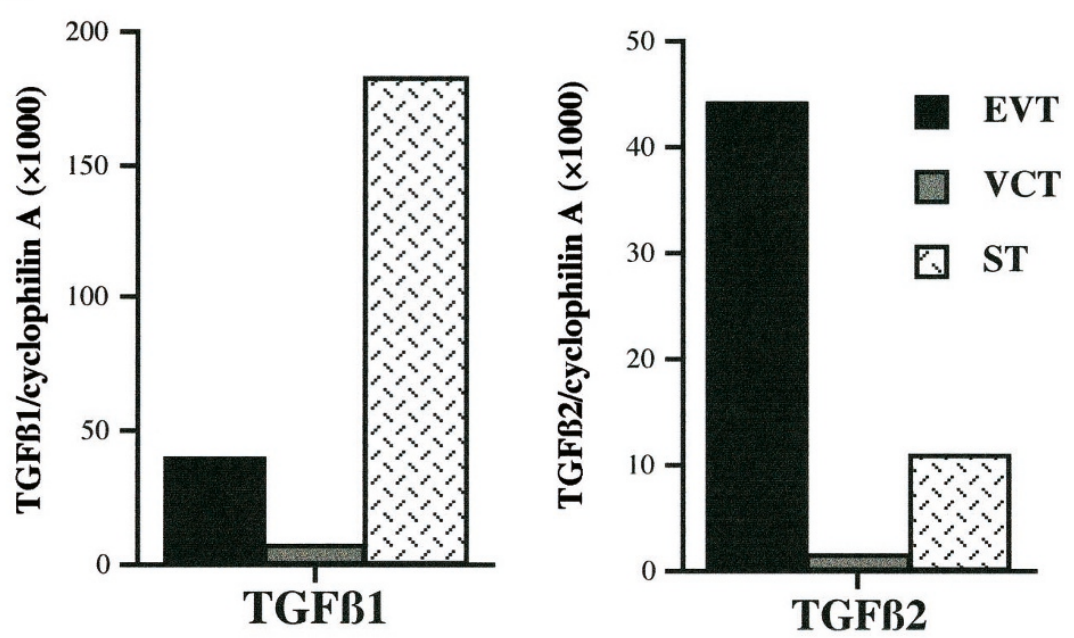

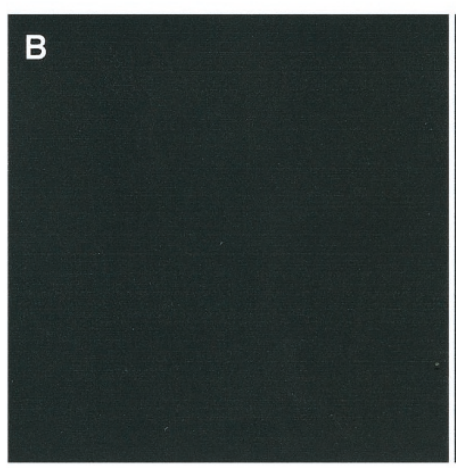

Non specific IgG

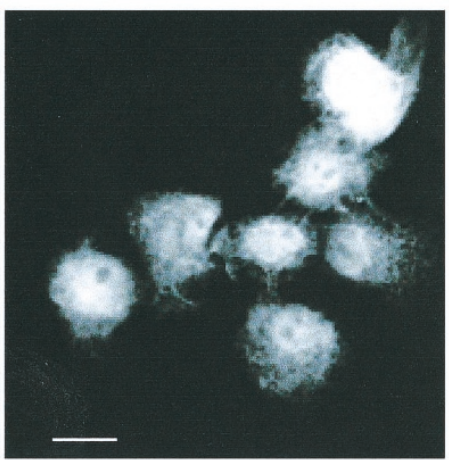

$A b$ against TGFB2

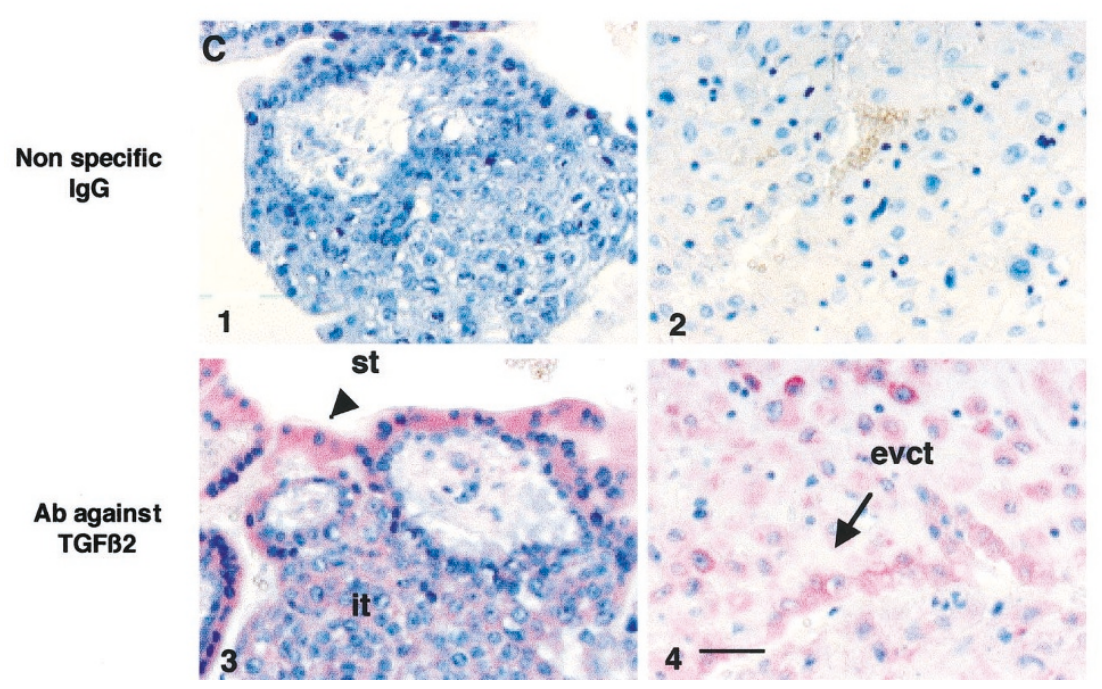

Figure 10.

TGF $\beta 2$ expression in human extravillous trophoblasts. A, TGF $\beta 1$ and TGF $\beta 2$ expression from human isolated VCT, ST cultured for 72 hours, and EVCT cultured for 48 hours on Matrigel by real-time PCR. Data are reported as the number of transcripts of TGF $\beta 1$ and TGF $\beta 2$ per the number of transcripts for the constitutive housekeeping gene product cyclophilin A. TGF $\beta 1$ is highly expressed in the ST, whereas TGF $\beta 2$ is highly expressed in EVT. B, Immunostaining of TGF $\beta 2$ in cytotrophoblast cultured for 48 hours on Matrigel (scale bar, $50 \mu \mathrm{m}$ ). Left panel is the control in the presence of nonspecific immunoglobulins. C, Immunohistochemical labeling of TGF $\beta 2$ in the anchoring villi and in the decidua of first trimester human placenta. Strong staining is observed in ST (Panel 3), in intermediate trophoblasts (it) of the column (Panel 3) and in the EVCT localized in the decidua (Panel 4). No staining is observed in the lgG control Panel 1 and Panel 2 (scale bar, $50 \mu \mathrm{m}$ ). 
(30-45\%) was removed and washed with DMEM. Cells were diluted to $1 \times 10^{6} \mathrm{cells} / \mathrm{ml}$ with DMEM supplemented with $2 \mathrm{~mm}$ glutamine, $20 \%$ heat inactivated FCS, $25 \mathrm{~mm}$ HEPES, $100 \mathrm{Ul} / \mathrm{ml}$ penicillin, and $100 \mu \mathrm{g} / \mathrm{ml}$ streptomycin, then plated in 60-mm Falcon culture dishes $\left(3 \times 10^{6}\right.$ cells in $\left.3 \mathrm{ml}\right)$ and incubated as described above. Approximately $15.6 \times 10^{6} \pm 5 \times 10^{6}$ cells were obtained per gram of chorionic villi. Cells obtained by the Percoll procedure and after a 72 hours culture period were examined by electron microscopy and gene expression analysis.

\section{Electron Microscopy}

Cells were fixed in $2.5 \%$ glutaraldehyde in PBS, $\mathrm{pH}$ 7.4 , for 45 minutes at $4^{\circ} \mathrm{C}$. Cells were postfixed in $1 \%$ osmium tetroxide for 1 hour, dehydrated through a graded ethanol series, and embedded in Epon epoxy resin. Sections $(80-100 \mathrm{~nm})$ were stained with uranyl acetate and lead citrate and examined at $80 \mathrm{kV}$ with a JEOL (JEM-100S) electron microscope.

For scanning electron microscopy, cells were fixed with $2.5 \%$ glutaraldehyde in $0.1 \mathrm{~m}$ cacodylate buffer for 1 hour at room temperature. The cultures were then dehydrated with increasing concentrations of acetone and dried with a critical-point-drying apparatus (Balzers Union, Liechtenstein) using acetone and liquid $\mathrm{CO}_{2}$. The dried specimens were coated with a $30-\mathrm{nm}$ layer of gold in a vacuum evaporator.

\section{Invasion Assays}

To assess the invasive potential of cytotrophoblasts, cultured EVCT were plated on transwell inserts (6.5 $\mathrm{mm}$; Costar, Cambridge, Massachusetts) containing polycarbonate filters with $8-\mu \mathrm{m}$ pores as previously described (Genbacev et al, 1996). The upper side was coated with $10 \mu \mathrm{l}$ of pure Matrigel; $2.5 \times 10^{5}$ cells were plated in $200 \mu \mathrm{l}$ of DMEM supplemented with 10\% FCS, 2 mм glutamine, $25 \mathrm{~mm}$ HEPES, $100 \mathrm{Ul} / \mathrm{ml}$ penicillin, and $100 \mu \mathrm{g} / \mathrm{ml}$ streptomycin, and $600 \mu \mathrm{l}$ of the same medium was added to the well. Transwells were incubated in $5 \% \mathrm{CO}_{2}$ at $37^{\circ} \mathrm{C}$.

After 24 or 48 hours of culture, the transwell inserts were washed three times with PBS and cells were fixed for 1 hour in $4 \%$ paraformaldehyde at $4^{\circ} \mathrm{C}$. Samples were rinsed and fixed for 10 minutes at $-20^{\circ} \mathrm{C}$ in methanol. Cells were incubated with $7 \%$ goat serum in PBS for 30 minutes to reduce nonspecific binding. Cytokeratin 07 antibody (1:200; Dako, Trappes, France) diluted in PBS containing 1\% BSA was added for 3 hours at room temperature. Cells were washed in PBS-Tween $0.1 \%$ and incubated with FITC-conjugated goat antimouse IgG (Jackson Immunoresearch Laboratories, West Grove, Pennsylvania) for 1 hour and washed in PBS-Tween $0.1 \%$. Filters were dissected with a scalpel and the top of the filter face was placed in contact with a superfrost slide, mounted in mounting medium (Vector Laboratories, Burlingame, California), and examined and photographed on an Olympus BX60 epifluorescence microscope.

\section{Real-Time PCR}

The theoretical basis of this method has been previously described (Gibson et al, 1996; Heid et al, 1996). The expression of cyclophilin A, cytokeratin 07 , c-erbB1, c-erbB2, HLA-G, hPL, $\alpha$ hCG, $\beta$ hCG, INSL4, leptin, TGF $\beta 1$, and TGF $\beta 2$ were investigated by realtime PCR (7700 Prism; PE Biosystems, Foster City, California). The TaqMan system includes amplification primers and a dual-labeled fluorescent TaqMan probe. Most of the primers and probes used in this study are already published (Frendo et al, 2000) or accessible upon request to Dr. Vidaud. In addition, cyclophilin A levels were measured in each sample to control for sample-to-sample differences in RNA concentrations. Total RNA was extracted from cultured cells following the procedure of Qiagen (Courtabeuf, France). One microgram was denatured, and reverse transcription was performed for 30 minutes at $42^{\circ} \mathrm{C}$ with $1.5 \mathrm{~mm}$ random hexamers (Pharmacia, Uppsala, Sweden), 3 $\mathrm{mm} \mathrm{MgCl}, 75 \mathrm{~mm} \mathrm{KCl}, 50 \mathrm{~mm}$ Tris buffer (pH 8.3), 500 mM dNTP, $10 \mathrm{~mm}$ DTT, $10 \mathrm{U}$ RNasin Ribonuclease inhibitor (Promega, Madison, Wisconsin), and $50 \mathrm{U}$ Moloney virus-reverse transcriptase (Superscript II; Life Technologies, Paisley, United Kingdom) in a total of $20 \mu \mathrm{l}$. Amplification was carried out using a $50 \mu \mathrm{l}$ reaction volume (TaqMan PCR Core Reagent Kit; PE Biosystems). One microliter of the RT reaction was used for quantitative two-step PCR (10 minutes at $95^{\circ} \mathrm{C}$, followed by 40 cycles of 15 seconds at $95^{\circ} \mathrm{C}$ and 1 minute at $65^{\circ} \mathrm{C}$ ), in the presence of $200 \mathrm{~nm}$ specific forward and reverse primers; $100 \mathrm{~nm}$ of a specific fluorogenic probe; $5 \mathrm{~mm} \mathrm{MgCl} ; ; 50 \mathrm{~mm} \mathrm{KCl}$; $10 \mathrm{~mm}$ Tris buffer ( $\mathrm{pH}$ 8.3); $200 \mathrm{~mm}$ each of dATP, dGTP, and dCTP; $400 \mathrm{~mm}$ dUTP; and $1.25 \mathrm{U}$ AmpliTaq Gold. Each sample was analyzed in duplicate and a calibration curve constructed with 10-fold serial dilutions of total RNA extracted from first trimester placenta was run in parallel with each analysis. For each sample, the amounts of mRNA and cyclophilin A mRNA were determined from the standard curves. Gene expression levels were divided by the amount of cyclophilin A to obtain a normalized value. Cyclophilin transcript levels did not vary with the time in culture. Similar results were observed using other reference genes such as pleiotropin.

\section{Immunohistochemistry}

hPL Immunodetection. Paraffin tissue sections (4 $\mu \mathrm{m})$ of first trimester placenta were dewaxed in xylene and rehydrated. The slides were heated in a microwave oven for three 5 -minute periods in $10 \mathrm{~mm}$ citrate, $\mathrm{pH} 6$, cooled for 20 minutes, and washed in Tris buffered saline (TBS). Immunostaining was performed using a streptavidin-alkaline phosphatase immunostaining kit (Dako). Briefly, nonspecific antibody binding was blocked by incubation for 30 minutes in "blocking reagent" containing carrier protein. Antibody against hPL (1:500; Dako) was diluted in 1\% bovine serum albumin (BSA) and sections were incubated for 30 minutes. Sections were then washed and 
incubated with a biotinylated secondary antibody for 30 minutes at room temperature. Streptavidin-alkaline phosphatase was applied for 30 minutes, and staining was detected with the new fuchsin chromogen after 20 minutes. Nuclei were counterstained by incubation for 2 minutes with hematoxylin. Sections were mounted, examined, and photographed under an Olympus BX60 microscope. Controls were performed by omitting primary antibody or by incubating the sections with nonspecific rabbit lgG at the same concentration as the primary antibody.

TGF $\beta 2$ Immunodetection. Paraffin tissue sections (4 $\mu \mathrm{m})$ of first trimester placenta were dewaxed in xylene and rehydrated. Immunostaining was performed using a universal streptavidin-alkaline phosphatase immunostaining kit (Immunotech, Margency, France). Nonspecific antibody binding was blocked by incubation for 30 minutes in "blocking reagent" containing carrier protein. Two micrograms per milliliter of TGF $\beta 2$ antibody (Santa Cruz Biochemicals, Santa Cruz, California) was diluted in 1\% BSA and incubated with the sections for 2 hours at room temperature. Sections were washed in PBS-0.1\% Tween and incubated with a biotinylated secondary antibody for 1 hour. Streptavidin-alkaline phosphatase was applied for 45 minutes. Staining was detected with the fast red chromogen after 10 minutes. Nuclei were counterstained by incubation for 2 minutes with hematoxylin. Sections were mounted, examined, and photographed under an Olympus BX60 microscope. Controls were performed by omitting primary antibody or by incubating the sections with nonspecific rabbit IgG at the same concentration as the primary antibody.

\section{Immunocytochemistry}

Antibodies. The antibodies used for immunocytochemistry are listed in Table 1.

Fluorescence Double Labeling. After 48 hours of culture, EVCT were fixed in 4\% PFA for 20 minutes at room temperature, washed in PBS, and permeabilized for 4 minutes in $0.3 \%$ Triton X-100-PBS. Cells were incubated with $7 \%$ donkey serum in PBS or $7 \%$ goat serum in PBS for 30 minutes to reduce nonspecific binding. Primary antibodies diluted in PBS containing $1 \%$ BSA were added overnight at $4^{\circ} \mathrm{C}$. Anti-hPL was applied simultaneously with one of a panel of antibodies (Table 1) with the exception of TGF $\beta 2$. Cells were washed in PBS-0.1\% Tween, then incubated with a secondary antibody antirabbit IgG, donkey biotinylated species-specific $F\left(a b^{\prime}\right) 2$ fragment (Amersham, Les Ulis, France) for TGF $\beta 2$ at 1:200 or antibody antimouse IgG, goat biotinylated species-specific $F\left(a b^{\prime}\right) 2$ fragment (Amersham) for 1 hour and washed in PBS- $0.1 \%$ Tween. Staining was revealed with streptavidin-fluorescein (Amersham) diluted 1:400 and with a rhodamine-conjugated goat antirabbit IgG for hPL detection (Jackson Immunoresearch Laboratories, West Grove, Pennsylvania) diluted 1:200 in the dark for 1 hour. Slides were mounted in mounting medium (Vector Laboratories, Burlingame, California) and examined and photographed on an Olympus BX60 epifluorescence microscope. Controls were performed by omitting primary antibody or by nonspecific mouse IgG of the same isotype.

Peroxidase Immunocytochemistry. After 48 hours of culture, EVCT and ST were fixed in 4\% PFA for 20 minutes. Immunostaining was performed using a streptavidin-peroxidase immunostaining kit (Dako). Cells were incubated with $\mathrm{H}_{2} \mathrm{O}_{2}$. Afterward, nonspecific antibody binding was blocked by incubation for 30 minutes in "blocking reagent" containing carrier protein. Antibody against HLA-G (W6/32 clone that recognizes HLA-G, -C, $-E, 1: 130$; a gift from Dr. Le Bouteiller) was diluted in 1\% BSA and incubated for 2 hours at room temperature. Sections were washed in PBS- $0.1 \%$ Tween and incubated with a biotinylated secondary antibody for 1 hour. Streptavidin-peroxidase was applied for 30 minutes. Staining was detected with the chromogen after 10 minutes. Nuclei were counterstained by incubation for 2 minutes with hematoxylin. Sections were mounted, examined, and photographed under an Olympus BX60 microscope. Controls were performed by omitting primary antibody or by incubating the sections with nonspecific mouse lgG2a at the same concentration as the primary antibody.

\section{Flow Cytometry Analysis}

Cytotrophoblasts cultured on Matrigel were washed in HBSS after trypsinization and centrifugation. The suspension was adjusted to 500,000 cells $/ 100 \mu \mathrm{l}$ and incubated with $7 \%$ normal goat serum in HBSS for 10 minutes at $4^{\circ} \mathrm{C}$. Cells were washed and incubated with W6/32 antibody (recognizing HLA-G, -C, -E, 1:130; a gift from Dr. Le Bouteiller) or nonspecific mouse IgG2a diluted in HBSS containing 1\% BSA for 30 minutes at $4^{\circ} \mathrm{C}$. Cells were centrifuged at $300 \times g$

Table 1. Antibodies Used for Immunocytochemistry

\begin{tabular}{clccl}
\hline Antibody & Species & Isotype & Dilution & \multicolumn{1}{c}{ Source } \\
\hline $\begin{array}{c}\text { Cytokeratin } 07 \\
\text { (OV-TL }\end{array}$ & Mouse & $\operatorname{lgG} 1 \kappa$ & $1: 200$ & Dako, Trappes, France \\
12/30) & & & \\
$\alpha_{5}$ (SAM1) & Mouse & $\operatorname{lgG} 2 \mathrm{~b}$ & $1: 200$ & Coulter, Margency, France \\
C-erbB2 (9G6) & Mouse & $\operatorname{lgG1}$ & $1: 10$ & France Biochem, Meudon, France \\
hPL & Rabbit & - & $1: 500$ & Dako, Trappes, France \\
TGF $\beta 2$ & Rabbit & - & $1: 200$ & Santa Cruz Biochemicals, Santa \\
& & & & Cruz, California \\
\hline
\end{tabular}


for 10 minutes, and washed twice. Samples were incubated with FITC-conjugated $\mathrm{F}\left(\mathrm{ab} \mathrm{b}^{\prime}\right) 2$ goat antimouse (Coulter, Margency, France) for 30 minutes at $4^{\circ} \mathrm{C}$. The cells were washed in HBSS and analyzed in a Facs calibur Flow Cytometer (Becton Dickinson, Le Pont de Claix, France).

\section{Acknowledgements}

We thank the Department of Obstetrics and Gynecology at the Broussais and Saint Vincent de Paul Hospitals, Paris, for donating placental tissues. We also thank Nicole Burky for secretarial assistance.

\section{References}

Al-Lamki RS, Skepper JN, and Burton GJ (1999). Are human placental bed giant cells merely aggregates of small mononuclear trophoblast cells? An ultrastructural and immunocytochemical study. Hum Reprod 14:496-504.

Albrecht E and Pepe G (1990). Placental steroid hormone biosynthesis in primate pregnancy. Endocr Rev 11:124-150.

Alsat E, Guibourdenche J, Luton D, Frankenne F, and EvainBrion D (1997). Human placental growth hormone. Am J Obstet Gynecol 177:1526-1534.

Alsat E, Malassiné A, Tarrade A, Merviel P, and Evain-Brion D (1999). Le cytotrophoblaste humain, un casse-tête pour la biologiste. Médecine/Sciences 15:1236-1243.

Alsat E, Mirlesse V, Fondacci C, Dodeur M, and Evain-Brion D (1991). Parathyroid hormone increases epidermal growth factor receptors in cultured human trophoblastic cells from early and term placenta. J Clin Endocrinol Metab 73:288295.

Alsat E, Wyplosz P, Malassiné A, Guibourdenche J, Porquet D, Nessmann C, and Evain-Brion D (1996). Hypoxia impairs cell fusion and differentiation process in human cytotrophoblast, in vitro. J Cell Physiol 168:346-353.

Altman D, Schneider S, Thompson D, Cheng $\mathrm{H}$, and Tomasi T (1990). A TGF $\beta 2$-like immunosuppressive factor in amniotic fluid and localization of TGF $\beta 2$ mRNA in the pregnant uterus. J Exp Med 172:1391-1401.

Ando N, Hirahara F, Fukushima J, Kawamoto S, Okuda K, Funabashi T, Gorai I, and Minaguchi H (1998). Differential gene expression of TGF-beta isoforms and TGF-beta receptors during the first trimester of pregnancy at the human maternal-fetal interface. Am J Reprod Immunol 40:48-56.

Aplin JD (1991). Implantation, trophoblast differentiation, and haemochorial placentation: Mechanistic evidence in vivo and in vitro. J Cell Sci 99:681-692.

Benirschke K and Kaufmann P (2000). Early development of the human placenta. In: Pathology of the human placenta, 4th ed. New York: Springer-Verlag, 42-49.

Bischof P, Haenggeli L, and Campana A (1995). Gelatinase and oncofetal fibronectin secretion is dependent on integrin expression on human cytotrophoblasts. Mol Hum Reprod 10:734-742.

Boyd J and Hamilton W (1970). The human placenta. Cambridge: Heffer and Sons.

Caniggia I, Grisaru-Gravnosky S, Kuliszewsky M, Post M, and Lye $S$ (1999). Inhibition of TGF- $\beta 3$ restores the invasive capability of extravillous trophoblasts in preeclamptic pregnancies. J Clin Invest 103:1641-1650.

Cervar M, Blaschitz A, Dohr G, and Desoye G (1999). Paracrine regulation of distinct trophoblast functions in vitro by placenta macrophages. Cell Tissue Res 295:297-305.

Chen H, Yelavarthi K, and Hunt J (1993). Identification of TGF $\beta 1$ mRNA in virgin and pregnant rat uteri by in situ hybridization. J Reprod Immunol 25:221-233.

Clark D, Vince G, Flanders K, Hirte H, and Starkey P (1994). CD56+ lymphoid cells in human first trimester pregnancy decidua as a source of novel TGF $\beta 2$-related immunosuppressive factors. Hum Reprod 9:2270-2277.

Copeman J, Han RN, Caniggia I, McMaster M, Fisher SJ, and Cross JC (2000). Posttranscriptional regulation of human leukocyte antigen $\mathrm{G}$ during human extravillous cytotrophoblast differentiation. Biol Reprod 62:1543-1550.

Cronier L, Bastide B, Hervé J, Deleze J, and Malassiné A (1994). Gap junctional communication during human trophoblast differentiation: Influence of human choronic gonadotropin. Endocrinology 135:402-408.

Cronier L, Hervé J, and Malassiné A (1997). Regulation of gap junctional communication during human trophoblast differentiation. Microsc Res Tech 38:21-28.

Damsky C, Fitzgerald M, and Fisher S (1992). Distribution patterns of extracellular matrix components and adhesion receptors are intricately modulated during first trimester CT differentiation along the invasive pathway, in vivo. J Clin Invest 89:210-222.

Damsky C, Librach C, Lim K, Fitzgerald M, McMaster M, Janatpour M, Zhou Y, Logan S, and Fisher S (1994). Integrin switching regulates normal trophoblast invasion. Development 120:3657-3666.

Frendo J, Vidaud M, Guibourdenche J, Luton D, Muller F, Bellet D, Giovagrandi $Y$, Tarrade A, Porquet D, Blot $P$, and Evain-Brion D (2000). Defect of villous cytotrophoblast differentiation into syncytiotrophoblast in Down's syndrome. J Clin Endocrinol Metab 85:3700-3707.

Genbacev O, DeMesy Jensen K, Schubach Powlin S, and Miller R (1993). In vitro differentiation and ultrastructure of human extravillous trophoblast cells. Placenta 14:463-475.

Genbacev O, Joslin R, Damsky CH, Polliotti BM, and Fisher SJ (1996). Hypoxia alters early gestation human cytotrophoblast differentiation/invasion in vitro and models the placental defects that occur in preeclampsia. J Clin Invest 97:540-550.

Genbacev O, Zhou Y, Ludlow JW, and Fisher SJ (1997). Regulation of human placental development by oxygen tension. Science 277:1669-1672.

Gibson U, Heid C, and Williams P (1996). A novel method for real time quantitative RT-PCR. Genome Res 6:995-1001.

Graham C and Lala P (1992). Mechanism of placental invasion of the uterus and their control. Biochem Cell Biol 70:867-874.

Guibourdenche J, Tarrade A, Laurendeau I, Rochette-Egly C, Chambon P, Vidaud M, and Evain-Brion D (2000). Retinoids stimulate leptin synthesis and secretion in human syncytiotrophoblast. J Clin Endocrinol Metab 85:2550-2555.

Haigh T, Chen C, Jones CJ, and Aplin JD (1999). Studies of mesenchymal cells from 1st trimester human placenta: Expression of cytokeratin outside the trophoblast lineage. Placenta 20:615-625. 
Handwerger S (1991). Clinical counterpoint: The physiology of placental lactogen in human pregnancy. Endocr Rev 12:329-336.

Heid C, Stevens J, Livak K, and Williams P (1996). Real time quantitative PCR. Genome Res 6:986-994.

Jacquemin P, Alsat E, Oury C, Belyew A, Muller M, EvainBrion D, and Martial J (1996). The enhancers of the CS B, A, and $L$ genes: Progressive activation during in vitro trophoblast differentiation and importance of the DF-3 element in determining their respective activities. DNA Cell Biol 15:845854.

Jameson J and Hollenberg A (1993). Regulation of chorionic gonadotropin gene expression. Endocr Rev 14:203-221.

Jokhi P, King A, and Loke YW (1994). Reciprocal expression of epidermal growth factor receptor and c-erbB2 by noninvasive and invasive human trophoblast populations. Cytokine 6:433-442.

Jones CJ and Fox H (1991). Ultrastructure of the normal human placenta. Electron Microsc Rev 4:129-178.

Kaufmann P and Scheffen I (1992). Placental development. In: Polin RA and Fox WW, editors. Fetal and neonatal physiology. Philadelphia: W.B. Saunders, 47-56.

Keryer G, Alsat E, Tasken K, and Evain-Brion D (1998). Cyclic AMP-dependent protein kinases and human trophoblast cell differentiation in vitro. J Cell Sci 111:995-1004.

Kliman H, Nestler J, Sermasi E, Sanger J, and Strauss J (1986). Purification, characterization, and in vitro differentiation of cytotrophoblasts from human term placenta. Endocrinology 118:1567-1582.

Kovats S, Main E, Librach C, Stubblebine M, Fisher S, and DeMars R (1990). A class antigen, HLA-G, expressed in human trophoblasts. Science 248:220-223.

Lala PK and Hamilton GS (1996). Growth factors, proteases and protease inhibitors in the maternal-fetal dialogue. Placenta 17:545-555.

Lala PK, Khoo NKS, Guimond M-J, and Chakraborty C (1999). Control mechanisms in human trophoblast proliferation and invasiveness: Their derangement during trophoblastic tumor progression. Trophoblast Res 13:119-136.

Laurent A, Rouillac C, Delezoide AL, Giovangrandi Y, Vekemans M, Bellet D, Abitbol M, and Vidaud M (1998). Insulinlike 4 (INSL4) gene expression in human embryonic and trophoblastic tissues. Mol Reprod Dev 51:123-129.

Le Bouteiller $P$ and Blaschitz A (1999). The functionality of HLA-G is emerging. Immunol Rev 167:233-244.

Lea R, Underwood J, Flanders K, Hirte H, Banwatt D, Finotto S, Ohno I, Daya S, Harley C, and Michel M (1995). A subset of patients with recurrent spontaneous abortion is deficient in TGF $\beta 2$-producing "suppressor cells" in uterine tissue near the placental attachment site. Am J Reprod Immuno 34:5264.

Librach CL, Werb Z, Fitzgerald ML, Chiu K, Corwin NM, Esteves RA, Grobelny D, Galardy R, Damsky CH, and Fisher SJ (1991). $92 \mathrm{kd}$ type IV collagenase mediates invasion of human cytotrophoblasts. J Cell Biol 113:437-449.

Loke $Y$ and Burland K (1988). Human trophoblast cells cultured in modified medium and supported by extracellular matrix. Placenta 9:173-182.
Loke YW and King A (1995). Human trophoblast development. In: Human implantation: Cell biology and immunology. Cambridge: Cambridge University Press, 32-62.

Maquoi E, Polette M, Nawrocki B, Bischof P, Noël A, Pintiaux A, Santavicca M, Schaaps J, Pijnenborg R, Birembaut P, and Foidard J (1997). Expression of stromelysin-3 in the human placenta and placental bed. Placenta 18:277-285.

Masuzaki H, Ogawa Y, Sagawa N, Hosoda K, Matsumoto T, Mise H, Nishimura H, Yoshimasa $\mathrm{Y}$, Tanaka I, Mori T, and Nakao K (1997). Nonadipose tissue production of leptin: Leptin as a novel placenta-derived hormone in humans. Nat Med 3:1029-1033.

Mühlhauser J, Crescimanno C, Kaufmann P, Höfler H, Zaccheo D, and Castellucci M (1993). Differentiation and proliferation patterns in human trophoblast revealed by c-erbB2 oncogene product and EGF-R. J Histochem Cytochem 41: 165-173.

Redman C (1997). Cytotrophoblasts: Masters of disguise. Nat Med 3:610-611.

Redman C, Sargent I, and Starkey P (1993). Placental endocrinology. In: The human placenta: A guide for clinicians and scientists. Oxford: Blackwell Scientific Publications, 237272.

Rong-Hao L, Luo S, and Zhuang L (1996). Establishment and characterization of a cytotrophoblast cell line from normal placenta of human origin. Hum Reprod 11:1328-1333.

Selick C, Horowitz G, Gratch M, and Scott R (1994). Immunohistochemical localization of transforming growth factor-B in human implantation sites. J Clin Endocrinol Metab 78:592596.

Senaris R, Garcia-Caballero T, Casabiell X, Gallego R, Castro R, Considine R, Dieguez C, and Casanueva F (1997). Synthesis of leptin in human placenta. Endocrinology 138:45014504.

Sporn MB and Roberts AB (1992). TGF $\beta$ : Recent progress and new challenges. J Cell Biol 119:1017-1021.

Strickland S and Richards WG (1992). Invasion of the trophoblasts. Cell 71:355-357.

Vicovac L and Aplin JD (1996). Epithelial-mesenchymal transition during trophoblast differentiation. Acta Anat 156:202216.

Vuckovic M, Genbacev O, and Kumar S (1992). Immunohistochemical localisation of TGF $\beta$ in first and third trimester human placenta. Pathobiology 60:149-151.

Wilson NF and Snell WJ (1998). Microvilli and cell-cell fusion during fertilization. Trends Cell Biol 8:93-96.

Zhou Y, Damsky C, Chiu K, Roberts J, and Fisher S (1993). Preeclampsia is associated with abnormal expression of adhesion molecules by invasive cytotrophoblasts. J Clin Invest 91:950-960.

Zhou Y, Damsky C, and Fisher S (1997a). Preeclampsia is associated with failure of human cytotrophoblasts to mimic a vascular adhesion phenotype. J Clin Invest 99:2152-2164.

Zhou Y, Fisher S, Janatpour M, Genbacev O, Dejana E, Wheelock M, and Damsky C (1997b). Human cytotrophoblasts adopt a vascular phenotype as they differentiate. J Clin Invest 99:2139-2151. 